\title{
Factors Impacting the Attractiveness of Cai Rang Floating Market, Can Tho City
}

\author{
Nguyen Ngoc Quang ${ }^{1}$, Nguyen Ngoc Minh ${ }^{2}$, và Nguyen Quoc Nghi ${ }^{3}$ \\ ${ }^{1}$ Office of the People's Committee of Can Tho City, ${ }^{2}$ Tay Do University, ${ }^{3}$ Can Tho University, Vietnam \\ Corresponding Author: Nguyen Quoc Nghi
}

\begin{abstract}
The study aims to find out factors affecting the attractiveness of the Cai Rang floating market in Can Tho City. The study data were collected from 308 visitors by direct interviews. The study has pointed out five factors affecting the attractiveness of the floating market. They include natural landscape, local culture, understanding, promotion activities, and differentiation. The natural landscape has the most influence on the attractiveness of the Cai Rang floating market in Can Tho City. Besides, the study has proposed several policy implications to improve the attractiveness of the floating market.
\end{abstract}

Keywords: attractiveness, tourist, Cai Rang floating market

\section{INTRODUCTION}

Cai Rang floating market has been a unique tourist attraction of the Mekong Delta region for a long time. The Rough Guide Tourism Magazine has voted Cai Rang as one of the ten most impressive markets in the world. The market locates on the Cai Rang River which is about $6 \mathrm{~km}$ from the center of Can Tho City. It takes 30 minutes to reach the market by boat from the Ninh Kieu Quay (in Ninh Kieu District). Cai Rang floating market is a convenient point for trading activities among provinces because of its location on the waterway between Hau River and Xa No Canal. This is the reason why Cai Rang has the largest scale compared to other floating markets in the region. In this market, most goods are sold wholesale and they are diverse. The most sold products are fruits, vegetables, and ornamental flowers, followed by handicrafts and household appliances (pots, saucers, cups, plates, pans, etc.), and food (fish sauce, dried fish, monosodium glutamate, sugar, milk, etc.). Besides, there are small boats selling food and drinks as well as products for the daily needs of residents. These typical features have attracted plenty of domestic and international tourists. However, according to Nhan and Canh (2011), there exist challenges including limited tourism services, low traffic safety, and environmental pollution. Therefore, this study is conducted to determine factors influencing the attractiveness of the Cai Rang floating market in the city of Can Tho. This is a significant basis for building an action program to improve the image of the floating market in the mind of domestic and foreign tourists.

\section{THEORETICAL FRAMEWORK AND RESEARCH HYPOTHESES}

In the tourism sector, the destination image is important to both visitors and tourist destinations. The destination image is considered the brand of local tourism. A positive destination image improves the attractiveness and competitiveness of a tourist destination (Martín and Ignacio, 2008). According to Bloch (1986), a product's attractiveness is explained by the satisfaction created when the customer uses that product. If a product creates a high level of satisfaction, its attractiveness is 
high (O'Cass, 2000). As presented by Kapferer and Laurent (1985), four factors that influence the attractiveness of a product are (1) perceived importance, (2) perceived purchasing risk, (3) self-expression value, and (4) hedonic value. In the tourism aspect, the attractiveness of tourism products is influenced by many factors such as local culture, natural landscape, promotion, differentiation, and understanding level (Nghi, 2019). Based on the literature review, experts have proven affecting elements on the attractiveness of tourist destinations. As a result, research hypotheses are proposed below.

Natural landscape: Natural landscape is an essential tourism resource. Researches by Yang et al. (2011), Ngoc and Trinh (2015) showed that natural landscape has a positive impact on the attractiveness of tourist destinations. The more beautiful and attractive the natural landscape is, the more visitors desire to explore and experience. Thus, the study set out hypothesis H1: Natural landscape positively affects the attractiveness of Cai Rang floating market.

Indigenous culture: The Mekong Delta possesses the cultural characteristics of the water area. This brings the core value in the development of cultural tourism. Each locality has its history and features which help visitors to understand about the meaning of tourism types in different areas. According to Nghi (2019), local culture supports the attractiveness of the tourist destination. Therefore, the study proposes hypothesis H2: Local culture positively impacts the attractiveness of Cai Rang floating market.

Understanding: Product understanding reflects the product-related information captured in a customer's memory such as brand information, attributes, experiences, and situations of product use. Park et al. (1994) confirmed that product experience helps increase customer knowledge. A great understanding enhances the attractiveness of the destination to visitors (Nghi, 2019). Hence, hypothesis $\mathrm{H} 3$ is as follows:
Understanding beneficially affects the attractiveness of Cai Rang floating market.

Promotion: To attract travellers, marketing activities are an important tool. Local tourism promotion activities create an impressive and attractive destination image in the mind of tourists (Nhat, 2010; Felsenstein and Fleischer, 2003). Marketing has significantly improved the attractiveness of the tourist destination (Nghi, 2019). Therefore, the study suggests hypothesis H4: Promotion activities positively affect the attractiveness of Cai Rang floating market.

Differentiation: Product differentiation is the ability of a product to make a difference outperform its competitive products (Best, 2000). Understanding customer needs and applying them to a differentiated product creates a competitive advantage for the product itself (Dalrymple and Parsons, 2000). The differentiation positions the characteristics of a tourist destination, thereby creating its attractiveness (Nghi, 2019). As a result, the study suggests hypothesis H3: Understanding positively affects the attractiveness of Cai Rang floating market.

Based on the above research hypotheses, a qualitative research was conducted with eight tourists who have visited Cai Rang floating market. The result shows that tourists consider five affecting factor to the attractiveness of the market. They are natural landscape, indigenous culture, understanding, promotion, and differentiation. The research model on factors affecting the attractiveness of Cai Rang floating market in Can Tho City is proposed.

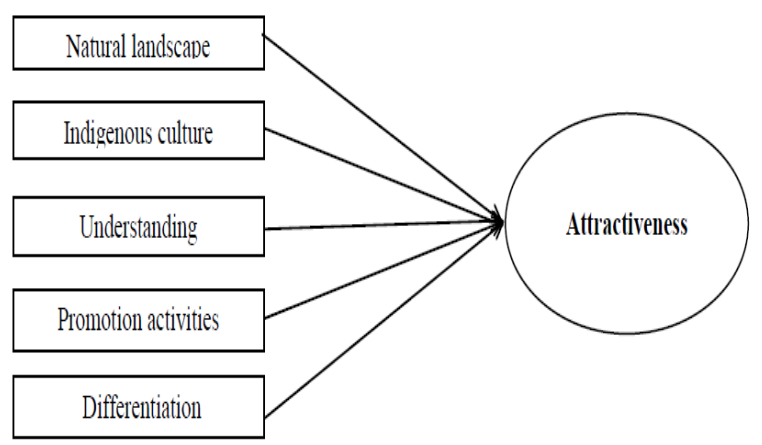

Figure 1: Proposed research model 
Nguyen Ngoc Quang et.al. Factors impacting the attractiveness of Cai Rang floating market, Can Tho City.

Table 1: Interpretation of observed variables in the research model

\begin{tabular}{|c|c|c|c|}
\hline Factor & Observed variables & Scale & Reference resources \\
\hline $\begin{array}{l}\text { Natural landscape } \\
(\mathrm{NL})\end{array}$ & $\begin{array}{l}\text { NL1. The natural landscape is attractive for traveling and } \\
\text { experiencing. } \\
\text { NL2. Rivers impress tourists with the beauty. } \\
\text { NL3. The landscape of the Cai Rang floating market is } \\
\text { natural and impressive. }\end{array}$ & $\begin{array}{l}\text { Likert } \\
1-5\end{array}$ & $\begin{array}{l}\text { Yang et al. (2011), Ngoc and Trinh } \\
\text { (2015) }\end{array}$ \\
\hline $\begin{array}{l}\text { Indigenous culture } \\
\text { (IC) }\end{array}$ & $\begin{array}{l}\text { IC1. Cai Rang floating market is bold in the watery culture. } \\
\text { IC2. Cai Rang floating market reflects the life of the local } \\
\text { communities on the river. } \\
\text { IC3. The commercial culture in Cai Rang floating market } \\
\text { interests tourists. }\end{array}$ & $\begin{array}{l}\text { Liket 1- } \\
5\end{array}$ & $\begin{array}{l}\text { Burkheiser (1969), Turtureanu (2005), } \\
\text { Nghi (2019) }\end{array}$ \\
\hline $\begin{array}{l}\text { Understanding } \\
\text { (UND) }\end{array}$ & $\begin{array}{l}\text { UND1. I am knowledgeable about different floating markets. } \\
\text { UND2. I know about Cai Rang floating market. } \\
\text { UND3. I know about tourism activities in Cai Rang floating } \\
\text { market. }\end{array}$ & $\begin{array}{l}\text { Likert } \\
1-5\end{array}$ & $\begin{array}{l}\text { Park et al. (1994), Brucks (1985), Nghi } \\
\text { (2019) }\end{array}$ \\
\hline $\begin{array}{l}\text { Promotion activities } \\
\text { (PA) }\end{array}$ & $\begin{array}{l}\text { PA1. There are plenty of promotion activities of the Cai } \\
\text { Rang floating market. } \\
\text { PA2. Marketing programs applied at Cai Rang floating } \\
\text { market are impressive. } \\
\text { PA3. The promoting information about Cai Rang floating } \\
\text { market is reliable. } \\
\text { PA4. It is easy to access information about Cai Rang floating } \\
\text { market. }\end{array}$ & $\begin{array}{l}\text { Liket } 1- \\
5\end{array}$ & $\begin{array}{l}\text { Felsenstein and Fleischer (2003), Nhat } \\
\text { (2010), Nghi (2019), }\end{array}$ \\
\hline $\begin{array}{l}\text { Differenciation } \\
\text { (DIF) }\end{array}$ & $\begin{array}{l}\text { DIF1. Cai Rang floating market has distinctive features from } \\
\text { other floating markets. } \\
\text { DIF2. Tourists experience attractive tourist services at Cai } \\
\text { Rang floating market. } \\
\text { DIF3. The local culinary is attractive. }\end{array}$ & $\begin{array}{l}\text { Likert } \\
1-5\end{array}$ & $\begin{array}{l}\text { Best (2000), Dalrymple and Parsons } \\
(2000)\end{array}$ \\
\hline $\begin{array}{l}\text { Attractiveness } \\
\text { (ATT) }\end{array}$ & $\begin{array}{l}\text { ATT1. The experience at Cai Rang floating market gives a } \\
\text { high level of relaxation. } \\
\text { ATT2. I feel the joy of visiting the Cai Rang floating market. } \\
\text { ATT3. Cai Rang floating market brings an exciting and novel } \\
\text { feeling. } \\
\text { ATT4. Cai Rang floating market meets the needs of } \\
\text { sightseeing, entertainment, and experience. }\end{array}$ & $\begin{array}{l}\text { Likert } \\
1-5\end{array}$ & Nghi (2019), Burkheiser (1969) \\
\hline
\end{tabular}

\section{RESEARCH METHODOLOGY}

\subsection{Analytical method}

The quantification of factors influencing the attractiveness of the Cai Rang floating market is conducted in three steps. (1) Testing the scale reliability by Cronbach's alpha. (2) Using Exploratory Factor Analysis (EFA) to group observed variables into statistically significant factors ensuring the suitability of market data. (3) Applying multivariate linear regression to determine the factors impacting the attractiveness of the Cai Rang Floating Market.

\subsection{Data collection method}

The study uses non-probability sampling, namely the convenient sampling. Green (1991) said that the appropriate sample size for multivariate regression analysis is $\mathrm{N}=50+8 \mathrm{~m}$, where $\mathrm{m}$ is the number of independent variables. In this study, five independent variables need at least 90 observations. According to Hair et al. (2006), the suitable size for the EFA should be $\mathrm{N}>5^{*} \mathrm{x}$ ( $\mathrm{x}$ is the total number of observed variables). The number of observed variables in this study is 16 , so the minimum sample size is 80 . To ensure representation and comprehension, the study interviewed two groups of tourists (domestic and international) visiting the market. The study collects data of 308 travelers, so the sample size is appropriate.

Table 2: Sample size description

\begin{tabular}{|l|l|l|l|}
\hline No & Survey object & $\begin{array}{l}\text { Number of } \\
\text { observations }\end{array}$ & $\begin{array}{l}\text { Percentage } \\
(\%)\end{array}$ \\
\hline 1 & Domestic tourist & 202 & 65.58 \\
\hline 2 & International tourist & 106 & 34.42 \\
\hline & Total & 308 & 100.00 \\
\hline
\end{tabular}

\section{RESEARCH RESULTS AND DISCUSSION \\ 4.1 Scale reliability test}

The study tests the reliability of observed variables by the Cronbach's alpha coefficient. Table 3 shows that Cronbach's alpha values are between 0.662 and 0.795 which means all scales are accepted (Peterson, 1994). Out of 20 observed variables, there is no corrected item-total 
correlation coefficient less than 0.3 , this proves that these variables can be included in the hypothesis test. Therefore, 20 observed variables can be used in the next exploratory factor analysis.

Table 3: Testing the reliability of observed variables

\begin{tabular}{|l|l|l|l|l|}
\hline No. & Scale & Number of observed variables & Cronbach's Alpha & Min corrected item-total correlation \\
\hline 1 & Natural landscape (NL) & 3 & 0.748 & 0.497 \\
\hline 2 & Indigenous culture (IC) & 3 & 0.706 & 0.527 \\
\hline 3 & Understanding (UND) & 3 & 0.662 & 0.437 \\
\hline 4 & Promotion activity (PA) & 4 & 0.791 & 0.550 \\
\hline 5 & Differentiation (DIF) & 3 & 0.778 & 0.525 \\
\hline 6 & Attractiveness (ATT) & 4 & 0.795 & 0.550 \\
\hline
\end{tabular}

\subsection{Exploratory factor analysis (EFA)}

After the scale reliability test, exploratory factor analysis (EFA) is used to test the convergent and discriminant validity of variables. The first EFA with independent variables (natural landscape, indigenous culture, understanding, promotion, and differentiation) gives guaranteed values. Significance level (Sig.) $=0.00 \leq 0.05 ; \mathrm{KMO}=0.802(0.5 \leq \mathrm{KMO} \leq$ $1)$, factor loading of variables are greater than 0.5 . Total variance explained reaches $65.58 \%>50 \%$. These numbers show that the research data is consistent (Anderson and Gerbing, 1988). The EFA result creates five factors F1, F2, F3, F4, and F5. The observed variables belong to factors as the proposed model, so there is no change in factors' names. The EFA for the dependent variable (attractiveness) achieves the following results. Sig. $=0.00 \leq 0.05 ; \mathrm{KMO}$ $=0.720$ (in the range of $0.5 \leq \mathrm{KMO} \leq 1$ ); factor loading of variables are higher than 0.5 ; total variance explained is $62.11 \%>$ $50 \%$. Hence, the research data is consistent (Anderson and Gerbing, 1988). This result creates one factor (F6). All factors are summarized in the table below.

Table 4: Factors formed from the EFA result

\begin{tabular}{|l|l|l|}
\multicolumn{2}{c}{ Table 4: Factors formed from the EFA result } \\
\hline Sign & Observed variables & Factor \\
\hline F1 & 3 variables: IC1, IC2, IC3 & $\begin{array}{l}\text { Indigenous } \\
\text { culture }\end{array}$ \\
\hline F2 & 3 variables: NL1, NL2, NL3 & Natural landscape \\
\hline F3 & 4 variables: PA1, PA2, PA3, PA4 & $\begin{array}{l}\text { Promotion } \\
\text { activity }\end{array}$ \\
\hline F4 & 3 variables: DIF1, DIF2, DIF3 & Differentiation \\
\hline F5 & 3 variables: UND1, UND2, UND3 & Understanding \\
\hline F6 & $\begin{array}{l}\text { 4 variables: ATT1, ATT2, ATT3, } \\
\text { ATT4 }\end{array}$ & Attractiveness \\
\hline
\end{tabular}

\subsection{Multivariate linear regression}

After the EFA step, the multivariate linear regression is applied to determine factors affecting the attractiveness of the Cai Rang floating market. The results are in table 5 .

\begin{tabular}{|l|l|l|l|} 
Table 5: Multivariate linear regression result \\
\begin{tabular}{|l|l|l|l|}
\hline Factor & $\begin{array}{l}\text { Estimated } \\
\text { coefficient }\end{array}$ & Sig. & $\begin{array}{l}\text { Variance } \\
\text { inflation factor } \\
\text { (VIF) }\end{array}$ \\
\hline $\begin{array}{l}\text { Natural landscape } \\
\text { (NL) }\end{array}$ & 0.361 & 0.000 & 1.000 \\
\hline $\begin{array}{l}\text { Indigenous culture } \\
\text { (IC) }\end{array}$ & 0.290 & 0.000 & 1.000 \\
\hline $\begin{array}{l}\text { Promotion activity } \\
\text { (PA) }\end{array}$ & 0.291 & 0.000 & 1.000 \\
\hline $\begin{array}{l}\text { Differentiation } \\
\text { (DIF) }\end{array}$ & 0.236 & 0.000 & 1.000 \\
\hline $\begin{array}{l}\text { Understanding } \\
\text { (UND) }\end{array}$ & 0.252 & 0.000 & 1.000 \\
\hline Adjusted R & & & 0.408 \\
\hline $\begin{array}{l}\text { Durbin-Watson } \\
\text { stat }\end{array}$ & & & 1.967 \\
\hline Sig.F & & & 0.000 \\
\hline
\end{tabular}
\end{tabular}

Based on the result in table 5 , the significance of the model (Sig. $=0.00$ ) is smaller than 0.05 , so the model is statistically significant. The adjusted $\mathrm{R}^{2}$ value achieves 0.408 which means $40.8 \%$ in the attractiveness of the Cai Rang floating market is explained by factors in the model. The Durbin-Watson value is 1.967 meaning that there is no autocorrelation. Besides, the VIF value is less than 4 , so the model does not have multicollinearity.

The analysis indicates that the attractiveness of the Cai Rang floating market depends on the natural landscape, indigenous culture, understanding, promotion, and differentiation. All of these factors positively affect the attractiveness of the market. It concludes that if the market is invested in terms of indigenous culture, natural landscape, unique watery features, and marketing activities, the attractiveness will be improved. 


\section{CONCLUSION AND POLICY IMPLICATIONS}

The study has pointed out five factors that positively affect the attractiveness of the Cai Rang floating market in Can Tho City, including natural landscape, indigenous culture, understanding, promotion, and differentiation. In which, the natural landscape has the strongest influence on the attractiveness of the market. Based on the research results, several policy implications are proposed for the city's tourism industry.

Firstly, improve river vehicles. From the experiences of countries with developed river tourism, river transport plays an essential role and makes a special impression on tourists. Therefore, the city tourism industry should develop a typical kind of river-way vehicle that both maintains the river culture and ensures safety for visitors.

Secondly, develop river cultural festivals. River festivals are indispensable parts of the tourism development strategy of many countries. In Can Tho City, plenty of river cultural festivals have been held and increasingly developed. However, it is important to invest in developing regional, national, and international river festivals. This will be a highlight that attracts domestic and foreign tourists to Cai Rang floating market.

Thirdly, experience the commercial life. The local authority should focus on developing tourism services at Cai Rang floating market in the direction of diversifying tourism products, especially experiencing commercial lives. This can be the tool that helps position tourism products of the Cai Rang floating market in the future.

Fourthly, protect the water environment. With the impact of industry, water resources at Cai Rang floating market are being strongly affected. In addition to this, the waste discharge of riverine communities has led to serious pollution of the water environment. Therefore, protecting the river environment, regenerating rivers and small canals are necessary to maintain clear flows and the connection between tourist destinations.

\section{Acknowledgement: None}

\section{Conflict of Interest: None}

\section{Source of Funding: None}

\section{REFERENCES}

1. Anderson, J. C., \& Gerbing, D. W. (1988). Structural equation modeling in practice: A review and recommended two-step approach. Psychological Bulletin, 103(3), 411-423.

2. Best, R. J. (2005). Market-based management: Strategies for growing customer value and profitability. Upper Saddle River, NJ: Pearson/Prentice Hall.

3. Bloch, Peter H. (1986). Product Enthusiasm: Many questions, a few answers. Advances in Consumer Research, 13, 539-543.

4. Brucks, M. (1985). The effects of product class knowledge on information search behavior. Journal of consumer research, 12(1), 1-16.

5. Burkheiser, U. (1969). Das Produkt als Bestimmungsfaktor der Absatzpolitik: ein Versuch zur Weiterentwicklung der Absatztheorie (Doctoral dissertation, Verlag nicht ermittelbar).

6. Dalrymple, D. J., \& Parsons, L. J. (2000). Basic marketing management $\left(2^{\text {nd }} e d\right)$. New York: John Wiley \& Sons.

7. Felsenstein, D., \& Fleischer, A. (2003). Local festivals and tourism promotion: The role of public assistance and visitor expenditure. Journal of Travel Research, 41(4), 385-392.

8. Green, S. B. (1991). How many subjects does it take to do a regression analysis? Multivariate behavioral research, 26(3), 499-510.

9. Hair, J. F., Black, W. C., Babin, B. J., Anderson, R. E., \& Tatham, R. (2006). Multivariate data analysis ( $6^{\text {th }}$ ed.). Upper Saddle River, NJ: Pearson University.

10. Kapferer, J. N., \& Laurent, G. (1985). Consumer involvement profiles: a new and practical approach to consumer involvement (No. hal-00786782).

11. Ngoc, K. M., \& Trinh, N. T. (2015). Factors affecting tourists' return intention towards 
Vung Tau city, Vietnam-A mediation analysis of destination satisfaction. Journal of Advanced Management Science, 3(4), 292298.

12. Nguyen Quoc Nghi (2019). Factors affecting the attractiveness level of rural tourism development models in Phong Dien District, Can Tho City. Dong Nai University Journal of Science, 14, 29-38.

13. Nhan, N. T., \& Canh, D. N. (2011). Current status and solutions for tourism activity development at Cai Rang floating market in Can Tho City. Can Tho University Journal of Science, 19a, 60-71.

14. Nhat, N. T. T. (2010). Local marketing strategies to attract tourists to Da Nang City. Journal of Science and Technology - the University of Da Nang, 5(40), 215-224.

15. O'Cass, A. (2000). An assessment of consumers' product, purchase decision, advertising, and consumption involvement in fashion clothing. Journal of Economic Psychology, 21(5), 545-576.

16. Park, C. W., Mothersbaugh, D. L., \& Feick, L. (1994). Consumer knowledge assessment. Journal of consumer research, 21(1), 71-82.

17. Peterson, R. A. (1994). A meta-analysis of Cronbach's coefficient alpha. Journal of consumer research, 21(2), 381-391.

18. San Martín, H., \& Del Bosque, I. A. R. (2008). Exploring the cognitive-affective nature of destination image and the role of psychological factors in its formation. Tourism Management, 29(2), 263-277.

19. Turtureanu, A. G. (2005). Tourism products: Characteristics and forms. Acta Universitatis Danubius. Economica, 1(1), 141-157.

20. Yang, Q., Ye, F., \& Yan, F. (2011). An empirical analysis of influential factors in international tourism income in Sichuan Province. Asian Social Science, 7(3), 54-61.

How to cite this article: Nguyen Ngoc Quang, Nguyen Ngoc Minh, và Nguyen Quoc Nghi. Factors impacting the attractiveness of Cai Rang floating market, Can Tho City. International Journal of Research and Review. 2021; 8(5): 120-125. DOI: https://doi.org/10.52403/ijrr. 20210518 